\title{
KINERJA PERUSAHAAN UMUM JAMINAN KREDIT INDONESIA KANTOR WILAYAH KALIMANTAN TENGAH DALAM MENGEMBANGKAN UMKM DI KOTA PALANGKARAYA
}

\author{
General company performance Credit Guarantee Indonesia Central Kalimantan Regional Office \\ in developing SMES in Palangkaraya City
}

\section{Irwani* \\ Sutarno}

Universitas Muhammadiyah Palangkaraya, Palangka Raya,

Central Kalimantan, Indonesia

email:

irwani@umpalangkaraya.ac.id

\section{Kata Kunci:}

Kinerja

Jaminan

Perusahaan Kredit

Keywords:

Performance

Assurance

Credit Company

\section{Accepted}

January 2016

Published

April 2016

\begin{abstract}
Abstrak
Penelitian ini bertujuan untuk mengetahui kinerja perusahaan yang serasa dinilai mengalami penurunan dalam mengembangkan UMKM dikota Palangka Raya, yang selama ini turut membantu menumbuhkan perekonomian baik tingkat regional maupun nasional dengan cara memberikan jaminan kepada pelaku UMKM melalui bank pelaksana yang dilanjutkan ke perusahaan umum Jaminan Kredit Indonesia.
\end{abstract}

Penelitian ini menggunakan pendekatan penelitian kualitatif dengan tehnik analisa deskriptif. Kedudukan penelitian dalam penelitian kualitatif, penelitian yang memanfaatkan wawancara terbuka untuk menelaah dan memahami sikap, pandangan, perasaan dan perilaku individu atau sekelompok orang.

Berdasarkan hasil penelitian di Perusahaan Umum Jaminan Kredit Indonesia Kantor Wilayah Kalimantan Tengah dalam kinerjanya terdapat penurunan yang mengakibatkan tidak tercapainya suatu target, dari target yang di tentukan baik perusahaan maupun pemerintah, faktor yang ditemui dalam penurunan kinerja perusahaan umum Jaminan kredit Indinesia Kantor Wilayah Kalimantan Tengah yaitu (I). pelaku UMKM jumlahnya mencapai 25.000 dan tercatan di PLUT baru 17.000 pelaku UMKM saja yang telah terdata, sementara dari 17.000 pelaku UMKM yang terdata oleh PLUT baru 3.342 yang telah dijaminkan. (2) dari Perusahaan sendiri belum bertindak maksimal kepada kreditur dalam pemberian kredit kepada pelaku UMKM. (3) sampai saat ini pelaku UMKM masik memiliki kendala dalam mengembangkan usahanya dan kendalan yang paling besar yaitu modal. (4) para karyawan selama ini ternyata belum dapat menjelaskan fungsi dan peran perusahaan dalam membantu akses kredit bagi UMKM sehingga para pelaku UMKM tidak banyak yang tahu tentang perusahaan Penjaminan. (5) pada umumnya setiap perusahaan memiliki kendala baik eksternal maupun internal dan hal itu juga dialami oleh Perum Jamkrindo, salah satunya adalah pembayaran klaim bagi pelaku UMKM yang mengalami kegagalan usaha.

\footnotetext{
Abstract

This research aims to determine the company's perceived performance in developing SMEs and Palangka Raya, which has helped to foster the economy both regional and national levels by providing assurance To SMEs through the domiciled Bank which is continued with the general company of Indonesian credit guarantee.

The study used a qualitative research approach with descriptive analytical techniques. The position of research in qualitative research, research using open interviews for the study and attitudes, views, feelings and behaviors of retail or group of people.

Based on the results of the research on the credit assurance of general company Indonesia Central Kalimantan region in its performance there is a decline that resulted in not reaching the target, from the target determined both the company and the government, factors In the implementation of general corporate credit insurance from the office of Indonesia Central Kalimantan region (I). SME actors number JOURS 25.000 and stepped in the new Plut 17.000 Msers own which is a record, Adviesraad of I 7.000 UMK that data by the new Plut 3.342 that changed is guaranteed. (2) from a successful company has not acted maximally to creditors in granting credit to SMEs. (3) To date, Masik UKM has constraints in developing its business and the greatest reliability that is capital. (4) Employees so far have not been able to explain the function and the role of the company in helping access credit for SMEs so that the SME actors do not know much about the guarantee company. (5) In general, many companies have constraints both external and internal and also experienced by Perum Jamkrindo, one of which is a claim payment for SMEs who suffer from business failure.
} 


\section{PENDAHULUAN}

UMKM (usaha Mikro, Kecil \& menengah), disatu sisi mempunyai peran yang sangat penting didalam pembangunan perekonomian Indonesia, di sisi lain sebagian besar UMKM menghadapi banyak masalah, diantaranya adalah permodalan serta sebagian besar Sumber Daya Manusianya berpendidikan rendah, hanya tamat Sekolah Dasar (SD), atau bahkan belum tamat Sekolah Dasar (Tambunan, 20I2). Hasil sensus Ekonomi 2006 menunjukan bahwa di Indonesia, 47,7 persen UMKM (usaha Mikro, Kecil \& menengah) belum memiliki rencana pengembangan atau memperluas usahannya setahun yang akan datang. Yang dimaksud dengan "mengembangkan/ memperluas usaha" yaitu rencana memperluas tempat usaha. Membuka cabang, meningkatkan keahlian atau lainnya. UMKM (usaha Mikro, Kecil \& menengah) yang tidak memiliki rencana tersebut dikarenakan kendala SDM yang masih rendah, masalah Pemasaran, namun masalah yang paling besar adalah masalah modal. Terlihat jelas, 50,2 persen UMKM (usaha Mikro, Kecil \& menengah) tidak memiliki rencana mengembangkan usahanya karena kesulitan modal. Usaha Mikro, Kecil dan menengah (UMKM) (usaha Mikro, Kecil \& menengah) adalah Usaha yang dilakukan sebagian besar Rakyat Diseluruh Negara, baik dinegara maju, maupun dinegara berkembang. Usaha kecil adalah usaha yang padat tenaga kerja, sehingga lebih besar peluanganya untuk menciptakan lebih banyak pekerja.

Di Indonesia, jumlah populasi UMKM (usaha Mikro, Kecil \& menengah) pada tahun 2010 mencapai 54.II4.82, tahun 20II mencapai 55.206.444 unit usaha atau 99 persen terhadap total unit usaha di Indonesia, tahun 2012 mencapai 56.543.592, tahun 2013 mencapai 57.895.721, tahun 2014 mencapai 57.895.72I dan tahun 2015 mencapai 57.900.787. Tahun 2014, jumlah tenaga kerja yang bekerja di UMKM (usaha Mikro, Kecil \& menengah) mencapai 91,8 juta orang atau $97,3 \%$ terhadap seluruh tenaga kerja Indonesia. yang jumlahnya 104.613.68I orang. Tahun 20II jumlah kontribusi UMKM (usaha Mikro, Kecil \& menengah) pada PDB sebesar 57,95 persen, sedangkan perusahaan besar pemberian kontribusi pada PDB 42,6 persen.

UMKM (usaha Mikro, Kecil \& menengah) di kota Palangka Raya saat ini tengah berkembang walaupun tidak begitu pesat dan dalam rangka mengembangkan Usaha Menengah, Kecil dan Mikro, Pemerintah Provinsi Kalimantan Tengah, Khususnya Kota Palangka Raya melalui Dinas Koperasi dan UMKM (usaha Mikro, Kecil \& menengah) setempat bekerjasama dengan Perusahaan Umum Jaminan Kredit Indonesia dalam mengembangkan UMKM baik dalam pembinaan maupun penjaminan pinjaman modal. Tercatat hingga saat ini 27 Nopember 2015 (HarianTabengan Edisi 1815 th ke-5 Hal II) jumlah pelaku UMKM (usaha Mikro, Kecil \& menengah) di kota Palangka Raya sebanyak 17.500 orang pelaku UMKM (usaha Mikro, Kecil \& menengah) yang sudah terdata dan belum termasuk yang belum terdata dan sekarang masih berproses pendataan. pada periode. Maret $201 \mathrm{I}$ sampai 2013 Penjaminan UMKM (usaha Mikro, Kecil \& menengah) Perusahaan Umum Jaminan Kredit Indonesia (Perum Jarnkrindo) kantor Wilayah Kalimantan Tengah Untuk wilayah Provinsi Kalimantan Tengah adalah sebesar Rp. 788,7 $M$ dengan total Debitur (UMKM) (usaha Mikro, Kecil \& menengah) yang dijamin adalah sebanyak 4I.33I unit dan tenaga kerja sebanyak 50,929 orang di seluruh KalimantanTengah.

Pada periode yang sama, jumlah Penjaminan UMKM (usaha Mikro, Kecil \& menengah) Perusahaan Umum Jaminan Kredit Indonesia seluruh Indonesia adalah sebesar Rp. $57.34 \mathrm{~T}$ dengan total Debitur (UMKM) (usaha Mikro, Kecil \& menengah) yang dijamin adalah 3.337.846 unit dan tenaga kerja terserap sebanyak 4.555.64l orang. Jika dibandingkan dengan jumlah Penjaminan UMKM (usaha Mikro, Kecil \& menengah) 
Perusahaan Umum Jaminan Kredit Indonesia di seluruh Indonesia, maka penjaminan UMKM (usaha Mikro, Kecil \& menengah) di Provinsi Kalimantan tengah berkontribusi sebesar 6,62 \%, dan khusus di Kota Palangka Raya sebesar 3,13\% terdapat pencapaian penjaminan UMKM (usaha Mikro, Kecil \& menengah) Jamkrindo secara nasional.

Disinilah Kinerja Perusahaan Umum Jaminan Kredit Indonesia berperan Sebagai Lembaga Keuangan yang bergerak di bidang penjaminan, turut melaksanakan dan menunjang kebijakan serta program pemerintah di bidang ekonomi dan pembangunan nasional, dengan melaksanakan kegiatan penjaminan kredit bagi Usaha Mikro, Usaha Kecil dan Usaha Menengah, serta Koperasi, agar mendapatkan bantuan dana melalui pinjaman kepada Bank penyalur Kredit Usaha.

Menurut Mangkunegara (Pasolong, 2008:176) mengatakan bahwa kinerja adalah merupakan hasil kerja secara kualitas dan kuantitas yang dicapai oleh seseorang dalam melaksanakan fungsinya sesuai dengan tanggung jawab yang diberikan kepadanya.

Dari beberapa pendapat tersebut, menurut Robbin dan Coultar (Wibowo 2013:2) kinerja dapat dipandang dari perspektif hasil, proses atau perilaku yang mengarah pada pencapaian tujuan. Oleh karena itu, tugas dalam konteks penilaian kinerja, tugas pertama pimpinan organisasi adalah menentukan perspektif kinerja yang mana yang akan digunakan dalam memaknai kinerja dalam organisasi yang dipimpinya. Oleh karena itu dalam penilaian kinerja maka digunakanlah indikator kinerja sebagai pengukuran suatu kinerja. Indikator kinerja dapat dipakai untuk aktifitas yang hanya dapat ditetapkan secara lebih kualitatif atas dasar perilaku yang dapat diamati. Indikator kinerja juga menganjurkan sudut pandang prospektif (harapan kedepan) daripada retrospektif (melihat kebelakang).
Menurut Dwiyanto (2006:50) mengukur kinerja birokrasi publik berdasar adanya indikator yang secara lebih lanjut dijelaskan sebagai berikut:

a. Produktivitas Konsep produktivitas tidak hanya mengukur tingkat efisiensi, tetapi juga efektivitas pelayanan.

b. Kualitas Layanan Isu mengenai kualitas layanan cenderung semakin menjadi penting dalam menjelaskan kinerja organisasi pelayanan publik.

c. Responsivitas adalah kemampuan organisasi untuk mengenali kebutuhan masyarakat, menyusun agenda dan prioritas pelayanan, mengembangkan program-program pelayanan publik sesuai dengan kebutuhan dan aspirasi masyarakat.

d. Responsibilitas menjelaskan apakah pelaksanaan kegiatan organisasi publik itu dilakukan sesuai dengan prinsip-prinsip administrasi yang benar atau sesuai dengan kebijakan organisasi, baik yang eksplisit maupun implisit.

e. Akuntabilitas Publik menunjuk pada seberapa besar kebijakan dan kegiatan organisasi publik tunduk pada para pejabat publik yang dipilih oleh rakyat.

\section{METODOLOGI}

Penelitian ni menggunakan pendekatan kualitatif yang merujuk kepada pendapat Strauss dan Corbm (Basrowi dan Suwandi, 2008:I) penelitian kualitatif adalah penelitian yang menghasilkan penemuan penemuan yang tidak dapat dicapai dengan menggunakan prosedur - prosedur statistik atau dengan cara kuantitatif lainnya. Penelitian kualitatif dapat digunakan untuk meneliti kehidupan masyarakat, sejarah, tingkah laku, fungsionalisasi organisasi, gerakan sosial, atau hubungan kekerabatan.

Berdasarkan teori tersebut, peneliti beralasan menggunakan metode kualitatif karena peneliti ingin memahami faktor sosiologis, situasi dan gejala atau 
fenomena sosial secara mendalam, dan komprehensif. Ditambah lagi permasalahan yang belum jelas, holistic, Kompleks, dinamis dan penuh makna.

\section{HASIL DAN PEMBAHASAN}

UMKM diakui memilik peran strategis bagi perekonomian nasional, namun kelompok usaha ini menghadapi sejumlah masalah persoalan yang menghambat perkembangannya. Persoalan yang di hadapi UMKM salah satunya adalah Permodalan. Pernodalan dirasa penting karena dengan modal itulah para pelaku UMKM dapat mengembangkan usahaanya, kendatipun tidak dapat mengembangkan usahanya setidaknya mereka bisa bertahan dengan adanya modal lebih.

Sampai saat ini pemerintah pusat maupun pemerintah daerah belum bisa memberikan kemudahan kepada para pelau UMKM untuk mengembangkan usahanya, padahal Peran pemerintah dalam hal ini sangat penting dan dibutuhkan. Lembaga pembiayaan merupakan salah satu kelompok yang memberdayakan UMKM dengan fokus pada permodalan sesuai dengan jalur usaha nya. Kelompok ini mencakup bank, koperasi, lembaga pembiayaan, pegadaian serta lembaga yang memperkuat peran lembaga keuangan dalam kredit melalui perusahaan penjaminan.

\section{Produktivitas}

Dilihat dari produktivitas sebenarnya bisnis penjaminan merupakan bisnis yang sangat membantu UMKM, hal ini terlihat dari data yang ada bahwa tercatat dari tahun 2010 sampai tahun 2015 ada sekitar 20 perusahaan yang bergerak dibidang penjaminan yang berdiri, hal iniberarti perusahaan Penjaminan sangat di butuhkan oleh para pelaku UMKM, salah satunya adalah Perusahaan Umum Jaminan Kredit Indonesia (Perum Jamkrindo) yang hingga saat ini terus berupaya membatu pelaku UMKM dalam mengembangkan usahanya.
Berdasarkan hasil penelitian, Perusahaan Umum Jaminan Kredit Indonesia khususnya kantor Cabang Palangka Raya belum dapat membantu seluruh pelaku UMKM dikarenakan kinerjanya yang belum maksimal, diantara kinerja yang belum maksimal salah satunya yaitu Kurangnya sosialisasi kepada Masyarakat tentang adanya perusahaan negara yang bergerak di bidang penjaminan, sehingga hanya beberapa saja yang dapat terbantu dan hal ini sangat merugikan di beberapa pihak baik pihak perbankan, pelaku UMKM maupun perusahaan menjamin sehingga terget yang diharapkan tidak tercapai.

Tercatat dari data yang saya peroleh dan dari hasil penelitian, di Kalimantan Tengah Termasuk Kota Palangka Raya pelaku UMKM jumlahnya mencapai 25.000 dan tercatan di PLUT baru 17.000 pelaku UMKM saja yang telah terdata, sementara dari 17.000 pelaku UMKM yang terdata oleh PLUT baru 3.342 yang telah dijaminkan oleh Perusahaan Umum Jaminan Kredit Indonesia. Dengan demikian perlu upaya dan kinerja yang lebih lagi guna terpenuhinya takget tersebut. target tersebut mengacu pada PP No. 4I Tahun 2008 tentang Perum Jamkrindo "Menyelenggarakan kegiatan usaha di bidang penjaminan kredit bagi Usaha Mikro, Usaha Kecil, dan Usaha Menengah, serta Koperasi.”

2. Kualitas Layanan

Perusahaan Umum Jaminan Kredit Indonesia Kantor Cabang Palangka Raya terus berupaya untuk meningkatkan kualitas layanan, misalnya meyakinkan kreditur dengan prinsip penjaminan sebagai pelengkap agunan agar kreditur melakukan penilaian yang cermat tentang kelayakan pemberian kredit, contohnya: 


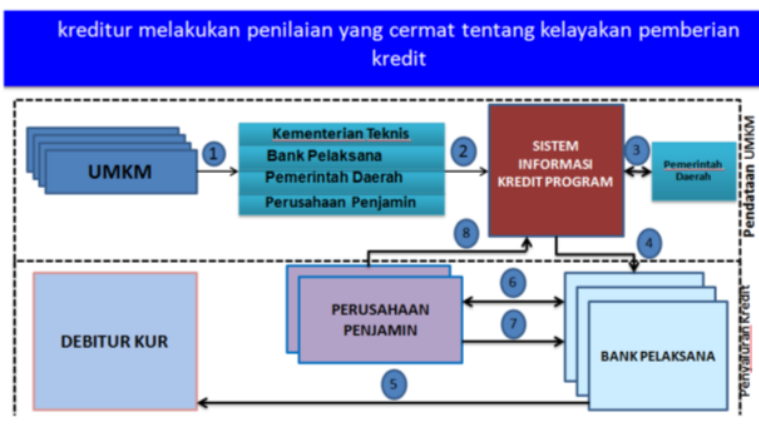

Sejauh ini sebenarnya sudah maksimal untuk tingkat kualitas layanan, tetapi hasilnya yang belum maksimal hal ini terlihat dari data yang ada bahkan dari tahun 2010 sampai dengan tahun 2015 penjaminan yang di jaminkan oleh Perusahaan Umum Jaminan Kredit Indonesia kantor Cabang Palangka Raya mengalami penurunan. Oleh karena itu harus diperbaiki dan di tingkatkan dalam kualitas layanannya kepada pelaku UMKM agar jumlah pelaku UMKM dapat meningkat. Tidak hanya itu Perusahaan umum Jaminan Kredit Indonesia Kantor Cabang Palangka Raya Paham terhadap apa yang menjadi kebutuhan pelaku UMKM seperti yang terjadi di lapangan, sebab itu tidak hanyak produksi, pemasaran, SDM yang menjadi permasalahan pelaku UMKM melainkan juga modal untuk mengembangkan usahanya. Perusahaan dituntut untuk lebih maksimal lagi sebab hal ini bukan hanya masalah mengembangkan pelaku UMKM tapi juga menumbuhkan perekonomian baik regional maupun nasional sebabini juga merupakan program pemerintah dan juga tugas perusahaan bertanggung jawab atas bidang usahanya.

3. Responsivitas

Mengenal kebutuhan masyarakat, menyusun agenda dan prioritas pelayanan, serta mengembangkan program-program sesuai dengan kebutuhan dan aspirasi masyarakat tentu merupakan respon positif perusahaan terhadap pelaku UMKM dan Perusahaan umum Jaminan Kredit Indonesia Kantor Cabang Palangka Raya Paham terhadap apa yang menjadi kebutuhan pelaku UMKM seperti yang terjadi di lapangan, sebab itu tidak hanyak produksi, pemasaran, SDM yang menjadi permasalahan pelaku UMKM melainkan juga modal untuk mengembangkan usahanya. "kendala pasti ada bahkan cenderung banyak, oleh karena banyaknya kendala tersebut maka kinerja kami mengalami penurunan yang berdampak pada kurangnya sosialisasi kepada mitra kerja dalam mengembangkan UMKM. Sehingga berakibat tidak tercapainya target yang di buat".

4. Responsibilitas

Tanggung jawab Perusahaan terhadap tugas-tugasnya yang berhubungan dengan peran kinerja perusahaan maupun pegawai kepada pihak yang dilayani termasuk pelaku UMKM semestinya di proiritaskan, sebab itu bagian dari kinerja perusahaan, jika tidak diprioritaskan maka akan semakin jauh dari target dan pencapaian kinerjanya pun tidak akan tercapai. Sebagai contoh, misalnya di lingkungan tempat tinggal karyawanterdapat pengusaha toko kelontong yang rame dan memerlukan tambahan modal untuk pengembangan usahanya.

Sebagai karyawan Perum Jamkrindo, maka karyawan dapat menjelaskan fungsi dan peran perusahaan dalam membantu akses kredit bagi UMKM yang memiliki usaha layak namun belum memenuhi persyaratan teknis perbankan, khususnya tidak memiliki agunan, atau memiliki agunan namun nilainya tidak memenuhi kebutuhan teknis/ persyaratan perbankan, karyawan dapat menceritakan peran perusahaan umum Jaminan Kredit Indonesia dalam mengembangkan UMKM secara langsung.

Dengan demikian maka tanggung jawab perusahaan terhadap tugas - tugasnya tidak terabaikan. Tidak hanya itu Pertanggungjawaban juga dapat diartikan sebagai proses antar pribadi yang menyangkut tindakan, perbuatan atau 
keputusan seseorang dalam hubungannya dengan orang lain sehingga dapat menerima hak dan wewenang tertentu berikut sanksi yang menjadi konsekuensinya. Contohnya Pengetahuan dasar tentang UMKMK penting bagi para karyawan Perusahaan Umum Jaminan Kredit Indonesia. Dasar hukum perusahaan (PP) menyebutkan secara khusus bahwa jasa penjaminan yang merupakan bisnis utama perusahaan hanya ditujukan untuk UMKM, oleh sebab itu pertanggungjawabanya besar, tidak hanya mempertanggungjawabkan status karyawannya para karyawan juga dituntut untuk memaksimalkan kinerjanya dengan memahami bisnis perusahaan sebagai penyedia jasa penjaminan kredit bagi pelaku UMKM oleh sebab itu diharapkan muncul kepedulian karyawan terhadap kebutuhan UMKM di lingkungannya dan Pemberian empati dapat dilakukan melalui pemahaman terhadap permasalahan UMKM yang dihadapi dan menyampaikan peran dan fungsi perusahaan kepada mereka.

5. Akuntabilitas.

Perusahaan Umum Jaminan Kredit Indonesia Kantor Cabang Palangka Raya sampai saat ini masih memiliki masalah yaitu permasalahan klaim yang mana hal ini menjadi pertanggung jawaban baik perusahaan maupun pihak perbankan yang menjadi mitra kerja, dengan adanya permasalahan tentu ini merugikan semua pihak baik perusahaan, perbankan maupun pelaku UMKM yang kesemuanya terkena dampaknya. Untuk itu Perusahaan Umum Jaminan Kredit Indonesia Kantor Cabang Palangka Raya hamur meningkatkan kinerjanya dalam mengembangkan UMKM khususnya di kota Palangka Raya karena itu bagian dari tanggung jawab perusahaan kepada program pemerintah untuk menumbuh kembangkan perekonomian baik yang saat ini kinerjanya belum maksimal.

\section{KESIMPULAN}

Peneliti dapat menyimpulkan bahwa Kinerja Perusahaan Umum Jaminan Kredit Indonesia Kantor Cabang Palangka Raya dalam Mengembangkan UMKM di Kota Palangka Raya memang harus ditingkatkan, sebab dari beberapa indikator permasalahan yang dihadapi oleh Perusahaan Umum Jaminan Kredit Indonesia Kantor Cabang Palangka Raya menyimpulkan beberapa permasalahan yang bermuara para menurunya kinerja perusahaan, hal ini dapat terlihat dari beberapa indikator kinerja yang terdiri dari Produksi, kualitas, tingkat pengenalan masyarakat terhadap perusahaan/produk perusahaan, tanggung jawab maupun akuntabilitas perusahaan yang kesemuannya menjelaskan adanya kekurangan dalam tingkat kinerjanya. Adapun saran yang diberikan sebgai berikut :

I. Disarankan Perusahaan Umum Jaminan Kredit Indonesia Kantor Cabang Palangka Raya dalam mengembangkan UMKM di Kota Palangka Raya lebih Maksimal lagi, agar para semua pihak Baik Perushaan, mitra kerja dan pelaku UMKM merasa diuntungkan.

2. Disarankan seluruh pegawai baik pimpinan sampai bawahannya selalu meningkatkan kualitas kinerjanya baik ke mitra kerja maupun ke pelaku UMKM, sebab bagaimanapun perusahaannya dan seperti apa alur kerjaanya, para karyawan harus lebih maksimal karena salah satu sumber rejekinya dari situ, tempatnya bekerja.

3. Perusahaan Umum Jaminan Kredit Indonesia Kantor Cabang Palangka Raya, Para Karyawan baik Pimpinan sampai bawahannya, mitra kerja dan para Pelaku UMKM harus saling percaya dalam meningkatkan hubungan kerja, demi tercapainya kinerja yang maksimal. 


\section{REFERENSI}

Anwar, Diding S. dan Pranoto, Toto. 2015. Industri Penjaminan Menatap Indonesia Gemilang. Jakarta. Lembaga Management FEB UI.

Basrowi dan Suawandi. 2008. Memahami Penelitian Kualitatif. Jakarta : PT. Rineka Cipta

Bugin, Burhan. 2010. Analisis Data Penelitian Kualitatif Pemahaman Filosofis dan Metodologi ke Arah Pengawasan Model Aplikasi. Jakarta: PT. Raja Grafindo Persada.

Idrus, Muhammad. 2009. Metode Penelitian IImu Sosial. Pendekatan Kualitatif dan Kuantitaif (Edisi Kedua). Jakarta. Erlangga

Mahmudi. 20I0. Manajemen Kinerja Sektor Publik, Edisi. kedua. Sekolah Tinggi Ilmu Manajemen YKPN. Yogyakarta.

Margono, S. 2003. Metode Penelitian Pendidikan. Jakarta: Rineka Cipta.

Pasolong, Harbani. 20II. Teori Administrasi Publik. Bandung: Alfabeta. Ratminto \& Atik Septi Winarsih. 2007. Manajemen Pelayanan. Yogyakarta: Pustaka Pelajar

Suwandi dan Baswori. 2008. Memahami Penelitian Kualitatif. Jakarta. PT. Reneka Cipta.

Yasarabi, Nasroen dan Dewi, Nina Kurnia. 2014. Penjaminan Kredit Mengantar UMKM Mengakses Pembiayaan. Bandung. PT. Alumni

Peraturan Pemerintah Nomor :4l Tahun 2008 Tentang "Perusahaan Umum Jaminan Kredit Indonesia".

Putra, C.A., Widyawati, N., Sailillah, M.S. 2014. Optimalisasi Handphone Untuk Monitoring
Ruangan Menggunakan Webcam Sebagai Peningkatan Kinerja Karyawan Pada Kantor Kelurahan Karang Mekar Kecamatan Banjarmasin Timur. Al Kalam: Jurnal Komunikasi, Bisnis, dan Manajemen. I(2): I - I3.

UU Republik Indonesia Nomor I Tahun 2016 tentang “Penjaminan".

Wibowo. 2007. Manajemen Kinerja. Jakarta. PT. Raja Grafindo Persada. 